\title{
ANALISIS SEMIOTIKA ROLAND BARTHES PADA FILM 3 DARA (KAJIAN SEMIOTIKA)
}

\author{
Asnat Riwu ${ }^{1}$, Tri Pujiati ${ }^{2}$ \\ Program Studi Sastra Indonesia, Universitas Pamulang \\ ${ }^{1}$ asnatriwu@gmail.com, ${ }^{2}$ dosen00356@unpam.ac.id
}

\begin{abstract}
Abstrak
Penelitian ini bertujuan untuk memaparkan wujud makna denotasi, makna konotasi, dan mitos yang terdapat di film " 3 Dara". Penelitian ini menggunakan deskriptif kualitatif dengan analisis semiotika dari Roland Barthes. Hasil yang diperoleh dari penelitian ini pada film "3 Dara" menemukan temuan-temuan sebagai berikut: (1) Makna denotasi dan konotasi pada film ini memberikan pemahaman kepada kita bahwa pentingnya bersikap sopan dan menghargai seorang perempuan dan kepada siapa pun. Karena apa pun yang kita tabur di dunia ini, baik itu perkataan, sikap baik dan buruk kepada sesama, kita akan menuainya suatu hari nanti. (2) Mitos yang dapat disimpulkan dalam penelitian ini adalah di saat Affandy, Jay, dan Richard mendatangi seorang psikolog dan psikolog tersebut mengklaim bahwa mereka mengalami Gender Diasyphora Syndrome, yaitu sebuah gejala di mana seorang pria secara perlahan memiliki perubahan sikap dan perilaku sebagai seorang wanita.
\end{abstract}

Kata Kunci: Film, Semiotika Roland Barthes

\begin{abstract}
This study aims to describe the form of denotation meaning, connotation meaning, and myth that is contained in the 3 Dara film. This study uses descriptive qualitative analysis with semiotics from Roland Barthes. The results obtained from this study in the film 3 Dara find the following findings: (1) The meaning of denotation and connotation in this film gives us an understanding that the importance of being polite and appreciating a woman and to anyone. Because whatever we sow in this world, be it words, good and bad attitudes toward others, we will reap it someday. (2) The myth that can be concluded in this study was when Affandy, Jay, and Richard came to a psychologist and psychologist who claimed that they experienced Gender Diasyphora Syndrome which is a symptom in which a man slowly changes his attitude and behavior as a woman.
\end{abstract}

Keywords: Film, Roland Barthes Semiotics

\section{PENDAHULUAN}

Film merupakan sarana baru yang digunakan untuk menyebarkan hiburan yang sudah menjadi kebiasaan terdahulu, serta menyajikan cerita, peristiwa, musik, drama, lawak, dan sajian teknis lainnya kepada masyarakat umum. Hal paling penting dalam film adalah gambar dan suara; kata yang diucapkan (di tambah dengan suarasuara lain yang serentak mengiringi gambar-gambar), dan musik film. Sistem semiotika yang lebih penting dalam film adalah digunakannya tandatanda ikonis, yakni tanda-tanda yang menggambarkan sesuatu yang digunakan dalam film mengisyaratkan pesan kepada penonton.

Film merupakan bidang kajian yang sangat relevan untuk analisis semiotika karena film dibangun dengan berbagai tanda. Tanda-tanda itu termasuk berbagai sistem tanda yang 
bekerja sama dengan baik untuk mencapai efek yang diharapkan. Film biasanya mempunyai makna seperti yang dikemukakan Roland Barthes, yaitu penanda (signifier) dan pertanda (signified). Biasanya penonton hanya mengetahui makna dari film secara menyeluruh, tetapi ketika film tersebut dianalisis, banyak sekali makna denotasi, konotasi, dan mitos, (Wirianto, 2016:27).

Salah satu rumah produksi yang sudah tidak asing lagi dalam dunia perfilman Indonesia, MNC Pictures merupakan rumah produksi yang selalu meramaikan dunia layar lebar dalam negeri. MNC Pictures didirikan pada tahun 2005 dan telah memproduksi beragam program dengan konten yang berkualitas dalam bentuk drama yang meliputi film, sinetron, show, reality show, musik, dan lain-lain. Salah Satu film rumah produksi ini adalah film "3 Dara".

Film ini selain bercerita tentang masalah pelik yang mereka hadapi juga menampilkan kekonyolan yang disertai lelucon khas anak muda saat ini dan juga film ini syarat akan adegan-adegan persahabatan dari ketiga tokoh utama. Pada adegan persahabatan tersebut, terdapat penanda (Signifier) dan petanda (Signified) yang digunakan untuk menemukan suatu petanda denotasi yang merupakan penanda konotatif. Semiotika merupakan suatu studi ilmu atau metode analisis untuk mengkaji tanda dalam suatu konteks skenario, gambar, teks, dan adegan di film menjadi sesuatu yang dapat dimaknai, sedangkan, kata "semiotika" itu sendiri berasal dari bahasa Yunani, semeion yang berarti "tanda" atau seme, yang berarti "penafsir tanda". (Kurniawan, 2001:49 dalam Mudjiono, 2011:129).

Melalui film "3 Dara”, penulis mencoba meneliti semiotika analitik yaitu semiotik yang menganalisis sistem tanda, semiotik normatif, yaitu semiotik yang khusus menelaah sistem tanda yang dibuat oleh manusia, semiotik sosial, yaitu semiotik yang menelaah sistem tanda yang dihasilkan oleh manusia yang berwujud lambing dan semiotik struktural, yaitu semiotik yang khusus menelaaah sistem tanda yang dimanifestasikan melalui struktur bahasa yang ada pada film tersebut. Berikut ini Penulis akan memaparkan contoh data yang terkait dengan analisis semiotika yang terdapat pada judul film ini sendiri yaitu kata Dara. Kata ini memiliki makna denotasi yang merupakan makna awal dari sebuah tanda, teks, dan sebagainya. Dengan kata lain, denotasi ini merujuk pada apa yang diyakini akal sehat/orang banyak. Jadi, menurut pemahaman orang pada umumnya ketika mendengar kata "Dara" yang muncul dibenak kita adalah seekor burung dara, yaitu nama lain burung merpati yang tergolong Familia Sternidae.

Pada pemaknaan konotasi yang merupakan istilah yang digunakan Barthes untuk menjelaskan salah satu dari tiga cara kerja tanda ditahapan kedua signifikansi tanda, menjelaskan interaksi yang terjadi ketika tanda bertemu dengan perasaan atau emosi dari pengguna dan nilai-nilai dalam kebudayaan mereka. Ketika masuk ke dalam makna konotasi, kata "Dara" merupakan sebutan lain untuk kata "perempuan". Barthes berpendapat bahwa faktor utama dalam konotasi adalah penanda dari tanda konotasi.

Selanjutnya, pada tahapan mitos sebagaimana dijelaskan oleh Barthes bahwa mitos merupakan cara yang kedua dalam cara kerja tanda di tatanan kedua. Penggunaan lazimnya adalah kata-kata yang menunjukkan ketidakpercayaan penggunanya. Mitos sebagai orang yang memercayainya 
dalam pengertian sebenarnya. Mitos adalah sebuah cerita di dalam suatu kebudayaan menjelaskan atau memahami beberapa aspek dari realitas atau alam. Jadi, mitos dari kata "Dara" sendiri adalah anak perempuan yang belum menikah dan masih perawan. Sedangkan kata "Dara" pada film ini bercerita tentang pria-pria yang dikutuk oleh seorang perempuan dikarenakan mereka menggoda perempuan tersebut. Adapun isi dari kutukan itu adalah suatu hari nanti kalian akan merasakan bagaimana rasanya menjadi perempuan yang dipermalukan. Dan mulai saat itu tingkah mereka mulai berubah, menjadi sangat sensitif, perasa, dan penuh empati.

\section{METODE PENELITIAN}

Metode penelitian merupakan cara untuk mencapai tujuan pokok permasalahan. Metode juga merupakan suatu kerangka kerja untuk melakukan tindakan atau suatu kerangka berpikir menyusun gagasan yang beraturan, terarah dan berkonteks, yang paut (relevance) dengan maksud dan tujuan. Sedangkan penelitian merupakan suatu kegiatan mengkaji (study) secara teliti dan teratur dalam suatu bidang ilmu menurut kaidah tertentu. Kaidah yang dianut ialah metode. Mengkaji ialah suatu usaha memperoleh atau menambah pengetahuan. Dalam penelitian ini digunakan metode penelitian kualitatif deskriptif dengan menggunakan metode simak sebagai alat penelitiannya.

Menurut Kountur (2009:108) penelitian deskripsi adalah jenis penelitian yang memberikan gambaran atau uraian atas suatu keadaaan sejelas mungkin tanpa ada perlakuan terhadap objek yang diteliti. Sedangkan Djajasudarma (2006:16) menjelaskan dalam metode deskriptif data yang dikumpulkan bukanlah angka-angka, dapat berupa kata-kata, atau gambaran sesuatu. Menurut Mahsun (2007: 93) dinamakan metode simak karena cara yang digunakan untuk memperoleh data dilakukan dengan menyimak penggunaan bahasa. Istilah menyimak di sini tidak hanya berkaitan dengan penggunaan bahasa secara lisan, tetapi juga penggunaan bahasa secara tertulis.

\section{HASIL DAN PEMBAHASAN}

1. Makna Denotasi dan Konotasi pada Film 3 Dara

Scene 5, $00: 02: 26-00: 05: 00$

\begin{tabular}{|c|c|c|}
\hline Sign & Signifier & Signified \\
\hline $\begin{array}{ll}- & \text { Dua } \\
\text { orang } \\
\text { - } & \text { Dalam } \\
& \text { ruangan } \\
\text { - } & \text { Lampu } \\
\text { kerlap- } & \text { kerlip } \\
\text { - } & \text { Pakaian } \\
& \text { berwarna } \\
\text { merah } \\
\text { dan biru }\end{array}$ & $\begin{array}{l}\text { Terdapat } \\
\text { dua } \\
\text { orang } \\
\text { sedang } \\
\text { berintera } \\
\text { ksi di } \\
\text { sebuah } \\
\text { ruangan } \\
\text { dengan } \\
\text { lampu } \\
\text { kerlap- } \\
\text { kerlip }\end{array}$ & $\begin{array}{l}\text { Terdapat } \\
\text { seorang } \\
\text { laki-laki } \\
\text { dan } \\
\text { seorang } \\
\text { perempuan } \\
\text { sedang } \\
\text { berdiri } \\
\text { sangat } \\
\text { dekat } \\
\text { dalam } \\
\text { sebuah } \\
\text { ruangan } \\
\text { dengan } \\
\text { lampu } \\
\text { kerlap- } \\
\text { kerlip. } \\
\text { Laki-laki } \\
\text { tersebut } \\
\text { mengenak } \\
\text { an jaket } \\
\text { berwarna } \\
\text { merah } \\
\text { hitam, } \\
\text { sedangkan } \\
\text { perempuan } \\
\text { mengenak } \\
\text { an baju } \\
\text { berwarna }\end{array}$ \\
\hline
\end{tabular}




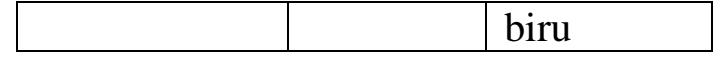

\section{Makna Denotasi}

Pengambilan gambar pada adegan tersebut menggunakan teknik Medium Close-Up. Dari penggambaran di atas dapat dijelaskan bahwa terdapat seorang laki-laki dan seorang perempuan dalam suatu ruangan dengan lampu kerlapkerlip. Tampak mereka sedang berkomunikasi. Laki-laki tersebut mengenakan baju berwarna abu-abu dan jaket berwarna merah hitam, sedangkan sang perempuan mengenakan baju berwarna biru.

\section{Makna Konotasi}

Teknik pengambilan gambar yang digunakan dalam adegan ini adalah medium close up (MCU) yaitu gambar yang diambil sebatas dari ujung kepala hingga dada. Fungsinya untuk mempertegas profil seseorang sehingga penonton jelas.

Pada scene terdapat percakapan antara perempuan dan laki-laki tersebut.

Richard: "Nomor telpon kamu deh."

Pelayan: "Heh sorry gak bisa, Mel udah tunangan."

Berdasarkan dialog tersebut makna konotasi yang ingin ditonjolkan oleh pembuat film adalah bahwa pria yang meminta nomor telepon wanita itu tertarik kepadanya. Namun, karena wanita tersebut sudah bertunangan, dia tidak bisa memberikan nomor teleponnya kepada pria itu. Wanita tersebut membatasi diri dalam pergaulan supaya tetap menjaga hubungan baik dengan pasangannya.

\begin{tabular}{|c|c|c|}
\hline sсепе 5, 00 & $22: 26-00$ & $15: 00$ \\
\hline Sign & Signifier & Signified \\
\hline $\begin{array}{cc}\text { - } & \text { Orang } \\
\text {-orang } \\
\text { sedan }\end{array}$ & $\begin{array}{l}\text { Sekumpula } \\
\mathrm{n} \quad \text { orang } \\
\text { tampak }\end{array}$ & $\begin{array}{l}\text { Dalam } \\
\text { gambar } \\
\text { terdapat tiga }\end{array}$ \\
\hline
\end{tabular}

\begin{tabular}{|l|l|l|}
\hline g & sedang & orang pria \\
berdiri & berkomuni & dan seorang \\
dan & kasi dalam & wanita. Satu \\
duduk & sebuah & pria sedang \\
- Ruang & ruangan. & duduk di \\
an & Terdapat & sofa, \\
- Meja & sofa dan & tampak \\
- Maka & meja, dan & memperhati \\
nan & di atas & kan \\
dan & meja ada & percakapan \\
botol & makanan & orang-orang \\
minu & dan botol- & yang \\
man & botol & berdiri. Pria \\
Sofa & minuman & lainnya \\
Tablet & & yang berdiri \\
& & sedang \\
& & melihat \\
& & tangan kiri \\
& & dari \\
& & perempuan \\
tersebut, \\
& & tangan \\
& & kanannya \\
& & tampak \\
& & memegang \\
tablet
\end{tabular}

\section{Makna denotasi}

Pengambilan gambar pada adegan ini menggunakan teknik Knee Shoot. Dari penggambaran di atas dapat dijelaskan bahwa terdapat tiga orang pria dan seorang wanita sedang berkomunikasi dalam suatu ruangan. Dalam ruangan tersebut terdapat sofa dan tempat duduk ketiga pria tersebut. Meja di depan tempat duduk mereka terdapat makanan dan botol minum. Terlihat pria yang di tengah sedang melihat tangan kiri dari perempuan, tangan kanan perempuan tersebut memegang sebuah tablet. Pria yang duduk memperhatikan orang-orang yang berdiri berkomunikasi.

\section{Makna konotasi}

Teknik pengambilan gambar yang digunakan dalam adegan ini adalah 
Knee Shoot (KS) yaitu pengambilan gambar sebatas kepala hingga lutut. Fungsinya memperlihatkan sosok objek secara jelas

Dari percakapan di atas tampak Jay dan teman-temannya menghina perempuan itu karena telah bertunangan. Makna konotasi yang ditonjolkan dalam adegan ini adalah bahwa sifat para pria-pria tersebut hanya ingin have fun dalam menjalin sebuah hubungan tanpa ingin berkomitmen.

Scene 5, $00: 02: 26-00: 05: 00$

\begin{tabular}{|c|l|l|}
\hline Sign & Signifier & \multicolumn{1}{|c|}{ Signified } \\
\hline - Seorang & Dalam & Terdapat \\
perempu & adegan & seorang \\
an & tersebut & perempuan \\
- Baju & terdapat & yang \\
warna & seorang & memakai \\
biru & perempua & baju \\
- Ruangan & n yang & berwarna \\
& memakai & biru sedang \\
& baju & berbicara \\
& berwarna & sambil \\
& biru & menunjuk \\
& & jari \\
& & telunjuknya \\
& & kepada \\
& & lawan \\
& & bicara, tanda \\
& & mempertega \\
& & s ucapannya \\
\hline
\end{tabular}

\section{Makna denotasi}

Teknik pengambilan gambar yang digunakan pada adegan ini adalah Medium Close-Up. Terdapat seorang perempuan yang memakai baju biru bergaris hitam sedang berbicara sambil menunjuk jari telunjuknya kepada lawan bicara untuk mempertegas ucapannya.

\section{Makna konotasi}

Teknik pengambilan gambar yang digunakan adalah Medium Close-up, yaitu gambar yang diambil sebatas dari ujung kepala hingga dada. Fungsinya untuk mempertegas profil seseorang sehingga penonton jelas.

Konotasi yang ingin disampaikan oleh pembuat film dalam adegan ini adalah bahwa Mel bukan tipe perempuan murahan yang suka digoda, melainkan perempuan baik yang menjunjung tinggi harkat dan martabat seorang perempuan. Dalam hal ini menjaga konsisten dalam sebuah hubungan

\section{Data 004}

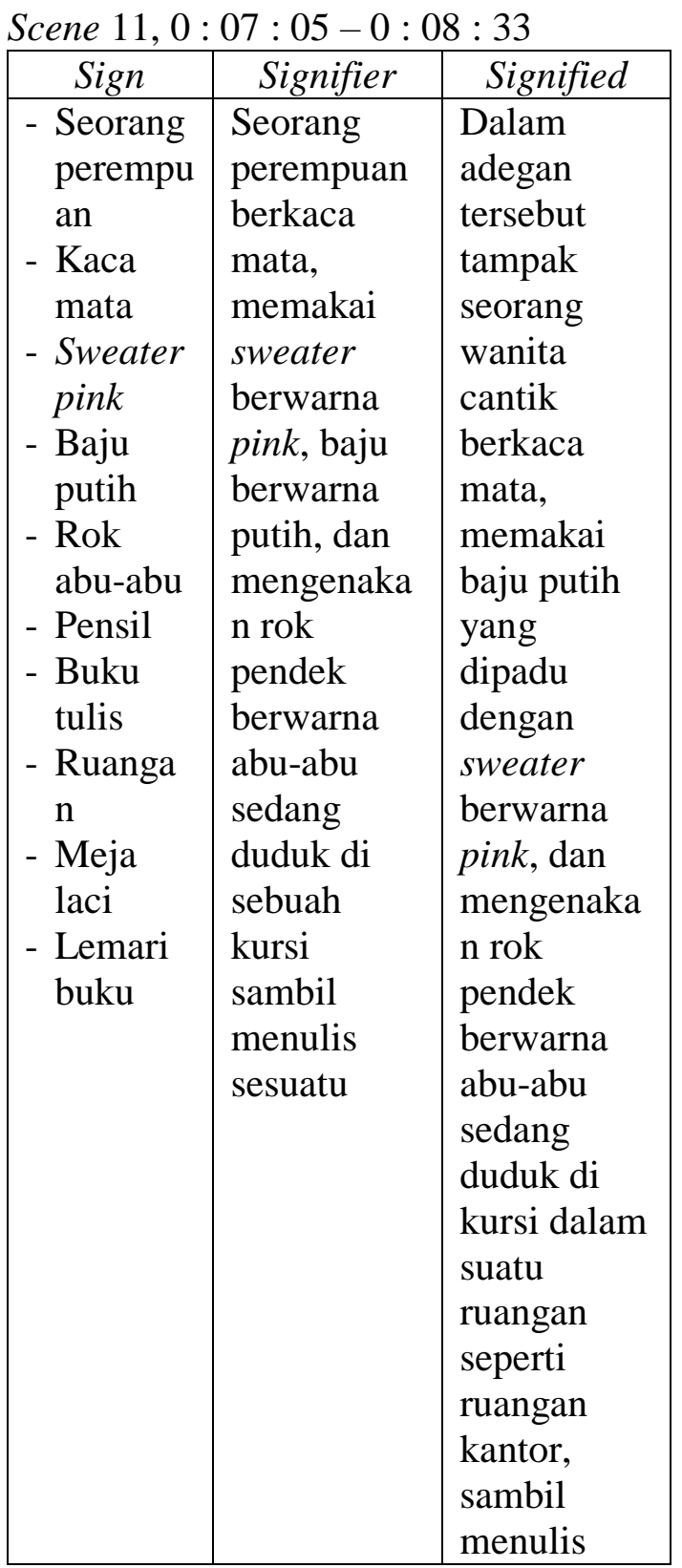




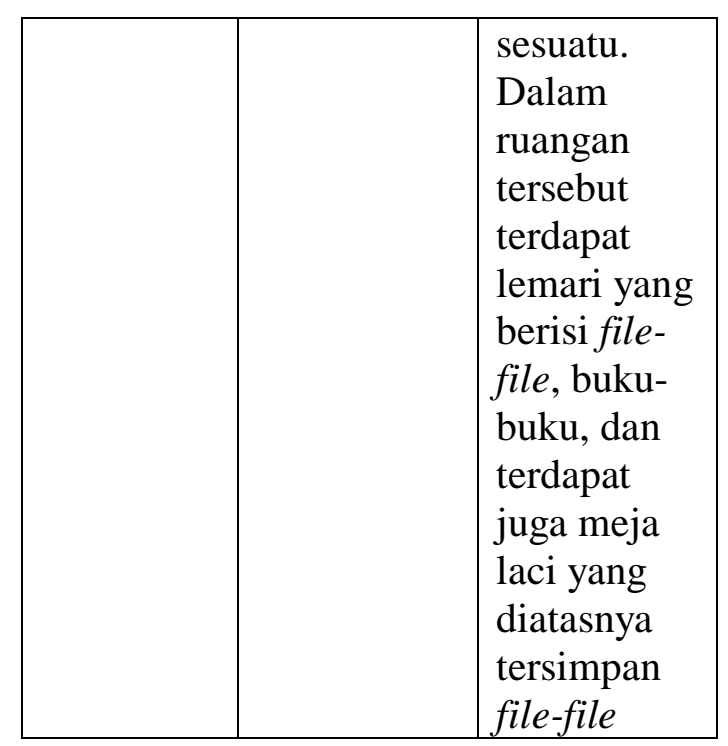

\section{Makna denotasi}

Teknik pengambilan gambar yang digunakan adalah Knee Shoot. Dalam sebuah ruangan terdapat seorang perempuan cantik berkaca mata sedang duduk di kursi sambil menulis sesuatu. Perempuan tersebut memakai baju berwarna putih dipadu dengan sweater berwarna pink dengan rok pendek berwarna abu-abu. Di belakangnya terdapat sebuah lemari tinggi berisi buku-buku dan file-file, dan sebuah meja laci.

\section{Makna konotasi}

Teknik pengambilan gambar yang digunakan pada adegan ini Knee Shoot, pengambilan gambar sebatas kepala hingga lutut. Fungsinya supaya memperlihatkan sosok objek secara jelas.

\section{Data 005}

Scene 12, 0:08:35-0:09:46

\begin{tabular}{|c|l|l|}
\hline Sign & \multicolumn{1}{|c|}{ Signifier } & \multicolumn{1}{c|}{ Signified } \\
\hline - Orang- & Terdapat & Dalam \\
orang & pria-pria & adegan \\
- Alam & sedang & tersebut \\
terbuka & berinteraksi & tampak \\
- Pohon- & sambil & empat orang \\
pohon & berjalan & pria sedang \\
\hline
\end{tabular}

\begin{tabular}{|l|l|l|}
\hline pelan di & berinteraksi \\
alam & sambil \\
terbuka. & berjalan \\
Terdapat & pelan di \\
banyak & tempat \\
pohon di & terbuka. \\
tempat & Terdapat \\
tersebut & banyak \\
& pohon di \\
& sekeliling \\
& & mereka. \\
\hline
\end{tabular}

\section{Makna denotasi}

Teknik pengambilan gambar yang digunakan adalah Mid Shoot. Dalam adegan tersebut terlihat ada empat orang pria sedang berjalan pelan sambil mengobrol di tempat terbuka. Pada latar adegan ini terdapat banyak pohon. Tampak pria yang berkacamata hitam yang berbicara, dan ketiga pria lainnya sedang mendengarkannya dengan serius.

\section{Makna konotasi}

Teknik pengambilan gambar yang digunakan dalam adegan ini adalah Mid Shoot, pengambilan gambar sebatas kepala hingga pinggang. Fungsinya memperlihatkan sosok objek secara jelas.

Adapun makna konotasi pada adegan ini adalah keseriusan mereka untuk datang berkonsultasi lagi. Hal ini bertanda bahwa mereka benar-benar tidak mampu menyelesaikan masalah yang mereka alami. Perkataan Guru O bahwa 'setiap sebab pasti ada akibat' sangat menohok di pikiran mereka.

\section{Data 006}

Scene 13, 0:09:47-0:12:36

\begin{tabular}{|c|l|l|}
\hline \multicolumn{1}{|c|}{ Sign } & \multicolumn{1}{c|}{ Signifier } & \multicolumn{1}{c|}{ Signified } \\
\hline - Pria-pria & Terdapat & Dalam \\
- Tempat & pria-pria & adegan \\
terbuka & sedang & tersebut \\
- Mobil & berdiri di & tampak tiga \\
- Bangunan & tempat & orang pria \\
\hline
\end{tabular}




\begin{tabular}{|c|c|c|}
\hline $\begin{array}{l}\text { bertingkat } \\
\text { - Bangunan } \\
\text { putih } \\
\text { - Pohon- } \\
\text { pohon }\end{array}$ & $\begin{array}{l}\text { terbuka } \\
\text { dekat } \\
\text { sebuah } \\
\text { mobil. } \\
\text { Dibelaka } \\
\text { ng } \\
\text { mereka } \\
\text { terlihat } \\
\text { bangunan } \\
\text { bertingka, } \\
\text { bangunan } \\
\text { putih, dan } \\
\text { pohon- } \\
\text { pohon. }\end{array}$ & $\begin{array}{l}\text { sedang } \\
\text { berdiri di } \\
\text { tempat } \\
\text { terbuka } \\
\text { tampak di } \\
\text { pinggir } \\
\text { jalan dekat } \\
\text { sebuah } \\
\text { mobil. Di } \\
\text { belakangny } \\
\text { a terdapat } \\
\text { bangunan } \\
\text { bertingkat, } \\
\text { gedung } \\
\text { putih, dan } \\
\text { pohon- } \\
\text { pohon. Satu } \\
\text { pria tampak } \\
\text { sedang } \\
\text { menutup } \\
\text { mukanya } \\
\text { dengan } \\
\text { kedua } \\
\text { tangannya, } \\
\text { pria di } \\
\text { tengah } \\
\text { terlihat } \\
\text { sedang } \\
\text { bingung, } \\
\text { dan pria } \\
\text { yang } \\
\text { lainnya } \\
\text { tampak } \\
\text { sedang } \\
\text { menutup } \\
\text { mulut } \\
\text { dengan } \\
\text { tangannya }\end{array}$ \\
\hline
\end{tabular}

\section{Makna denotasi}

Teknik pengambilan gambar yang digunakan dalam adegan ini adalah Mid Shoot. Pada adegan tersebut terlihat tiga pria sedang berdiri di tempat terbuka tampaknya di pinggir jalan. Tampak pria yang satu sedang menutup wajahnya dengan tangannya, pria yang di tengah tampak gelisah dan bingung, sedangkan pria lainnya tampak sama gelisahnya dengan menutup mulutnya. Di belakang mereka terdapat gedung berwarna putih, gedung bertingkat, dan pohon-pohon.

\section{Makna konotasi}

Teknik pengambilan gambar yang digunakan adalah Mid Shoot, yaitu pengambilan gambar sebatas kepala hingga pinggul. Fungsinya memperlihatkan sosok objek secara jelas.

Dalam perjalanan pulang dari guru $\mathrm{O}$, ketiga pria tersebut menceritakan keanehan-keanehan yang mereka alami. Beberapa saat kemudian, mereka mendengarkan lagu Raisa "Could It Be" yang diputar di radio mobil dan mereka ikut melantunkan lagu tersebut dengan gerakan-gerakan kecil yang tampak feminim. Affandy, yang menyetir mobil segera berhentikan mobil secara tiba-tiba yang membuat temannya bingung. Percakapannya adalah sebagai berikut:

\section{Data 007}

Scene 17, $0: 15: 26-0: 16: 52$

\begin{tabular}{|c|l|l|}
\hline Sign & Signifier & \multicolumn{1}{|c|}{ Signified } \\
\hline - Seorang & Terdapat & Dalam \\
pria & seorang & gambar \\
- Seorang & pria dan & tersebut \\
wanita & seorang & terlihat \\
- Ruang & wanita & seorang pria \\
makan & sedang & dan seorang \\
- Meja & duduk & wanita \\
makan & untuk & sedang \\
- Makanan & makan & duduk di \\
& & sebuah \\
& & meja makan \\
& & untuk \\
& & makan. \\
& & Tampak \\
& & sang pria \\
& & sedang \\
& & mengambil \\
& & nasinya \\
\hline
\end{tabular}




\section{Makna denotasi}

Teknik pengambilan gambar yang digunakan adalah Medium Close-up. Dalam adegan tersebut terdapat seorang pria dan seorang wanita sedang duduk di meja makan untuk makan. Tampak sang pria yang mengambilkan nasi dan lauk untuk wanita tersebut.

\section{Makna konotasi}

Teknik pengambilan gambar menggunakan teknik Medium Close-up, gambar yang diambil sebatas dari ujung kepala hingga dada. Fungsinya untuk mempertegas profil seseorang sehingga penonton jelas. Dalam adegan tersebut terjadi percakapan:

Konotasi yang ditonjolkan dalam adegan ini adalah sikap Affandy yang berubah terhadap istrinya di meja makan. Affandi selama ini dikenal sebagai sosok yang tidak menghargai wanita dan prinsipnya bahwa dibalik pria sukses ada wanita yang tertindas.

\section{Data 008}

Scene 18, 0:16:54-0:18:07

\begin{tabular}{|c|l|l|}
\hline Sign & Signifier & \multicolumn{1}{c|}{ Signified } \\
\hline - Gambar & Terdapat & Dalam adegan \\
seorang & sebuah & tersebut \\
peremp & gambar & memperlihatk \\
uan & seorang & an laptop yang \\
seksi & perempua & berisi gambar \\
- Ban & n seksi & seorang \\
mobil & dengan & perempuan \\
- Laptop & ban & cantik dan \\
& mobil. & seksi. \\
& Gambar & Disampingny, \\
& tersebut & terdapat \\
& terlihat & beberapa ban \\
& dalam & mobil. \\
& laptop & \\
\hline
\end{tabular}

\section{Makna denotasi}

Teknik pengambilan gambar yang digunakan dalam adegan ini adalah One Shoot. Pada adegan ini terlihat sebuah laptop. Dalam laptop tersebut terdapat gambar seorang perempuan cantik dan seksi, dan terdapat beberapa ban mobil disampingnya.

\section{Makna konotasi}

Teknik pengambilan gambar dalam adegan ini adalah One Shoot, pengambilan gambar satu objek. Fungsinya memperlihatkan seseorang/benda dalam frame.

Dari percakapan di atas konotasi yang ingin disampaikan adalah kebingungan Grace terhadap pacarnya karena tidak biasanya Jay bertanya tentang gambar-gambar untuk bacingnya kepada Grace. Selama ini, Buat Jay wanita itu objek, spesialisasinya ialah mengeksploitasi sensualitas wanita dan dia takut untuk berkomitmen.

\section{Data 009}

Scene 19, $0: 18: 08-0: 19: 30$

\begin{tabular}{|c|l|l|}
\hline Sign & \multicolumn{1}{|c|}{ Signifier } & \multicolumn{1}{c|}{ Signified } \\
\hline - Sebuah & Terdapat & Dalam \\
ruangan & seorang & adegan \\
- Seorang & pria & tersebut \\
pria & sedang & terdapat \\
- Handphon & berdiri & seorang \\
$e$ & dalam & pria sedang \\
& sebuah & berdiri \\
& ruangan & dengan \\
& dan & mengangka \\
& melihat & t kedua \\
& ke atas. & tangannya, \\
& Tanganny & dan melihat \\
& a & ke atas. \\
& memegan & Ditanganny \\
& g sebuah & a terdapat \\
& handphon & sebuah \\
& $e$ & handphone \\
\hline
\end{tabular}

\section{Makna denotasi}

Teknik pengambilan gambar yang digunakan adalah Knee Shoot. Pada adegan tersebut terlihat seorang pria dengan memakai kaos putih, celana panjang berwarna abu-abu sedang berdiri mengangkat kedua tangannya 
dan melihat ke atas. Adegan tersebut dalam sebuah ruangan.

\section{Makna konotasi}

Knee Shoot, pengambilan gambar sebatas kepala hingga lutut. Fungsinya memperlihatkan sosok objek secara jelas. Cerita dalam adegan tersebut adalah sebagai berikut:

Dalam percakapan di atas, makna konotasi yang ditonjolkan adalah perubahan pada Richard. Saat dia mulai merasa membutuhkan orang-orang yang dicintai, kekasihnya yang sangat diharapkan tiba-tiba memutuskan hubungan, dan secara bersamaan pula kekasihnya yang lain juga ikut memutuskan hubungan dengannya. Richard pun mulai merasa kesepian.

\section{Data 010}

Scene 23, $0: 23: 51-0: 23: 45$

\begin{tabular}{|c|l|l|}
\hline \multicolumn{1}{|c|}{ Sign } & \multicolumn{1}{|c|}{ Signifier } & \multicolumn{1}{c|}{ Signified } \\
\hline - Pria-pria & Dalam & Terdapat \\
- Tempat & adegan & tiga orang \\
terbuka & tersebut, & pria sedang \\
- Banguna & terdapat & berinteraks \\
n & pria-pria & i di tempat \\
- Pohon & sedang & terbuka. \\
& berinteraks & Tampak \\
& i di tempat & pria \\
& terbuka & ditengah \\
& & memegang \\
& & kedua \\
& & pundak \\
& & pria \\
& & lainnya. \\
& & Latar \\
& & dalam \\
& & adegan ini \\
& & terdapat \\
& & bangunan \\
& & dan pohon- \\
& & pohon \\
\hline
\end{tabular}

\section{Makna denotasi}

Teknik pengambilan gambar yang digunakan adalah Mid Shoot. Pada adegan tersebut terdapat tiga orang pria sedang berinteraksi di tempat terbuka. Tampak pria di tengah memegang kedua pundak kedua pria lainnya. Adapun latar dari dalam adegan ini adalah bangunan-bangunan dan pohonpohon.

\section{Makna konotasi}

Teknik pengambilan gambar yang digunakan adalah Mid Shoot, yaitu pengambilan gambar sebatas kepala hingga pinggul. Fungsinya memperlihatkan sosok objek secara jelas.

\section{Mitos dalam Film 3 Dara Data 001}

Setelah melalui pemahaman konotasi yang terdapat pada data 001, terdapat mitos atau ideologi yang berkembang di tengah masyarakat bahwa sepasang kekasih melakukan pertunangan terlebih dahulu sebelum melanjutkan ke jenjang pernikahan. Pertunangan sendiri dilakukan supaya pasangan mempersiapkan diri secara lahir dan batin untuk memasuki kehidupan rumah tangga. Dalam proses menjalin hubungan selama bertunangan tentulah bukan suatu hal yang mudah. Masing-masing harus menurunkan egonya supaya hubungan mereka tetap langgeng sampai hari pernikahan.

Beberapa pria sangat suka menggoda perempuan, tidak peduli status perempuan yang mereka goda adalah seorang janda, sudah mempunyai suami, sudah mempunyai kekasih, atau tunangan orang. Ini bias menjadi salah satu ujian khususnya untuk para perempuan, untuk menguji seberapa besar cintanya terhadap pasangannya. Perempuan baik, yang mencintai kekasihnya tentu akan menghindari rayuan-rayuan para lelaki seperti ini. Sikap tegas sangat diperlukan saat itu supaya tidak termakan rayuannya. 


\section{Data 002}

Pada data 002 diceritakan bahwa Affandy, Jay, dan Richard menggoda seorang pelayan perempuan di cafe yang bernama Mel. Perkataan Affandy yang terdapat dalam makna konotasi pada data 002 mengatakan "Lagian kamu cari apa sih mau kawin cepatcepat? Happy? Bullshet."

Yang sebenarnya menikah bukanlah mencari kebahagiaan, tetapi memberi kebahagiaan kepada pasangan. Kesuksesan pernikahan adalah timbulnya saling mencintai antara suami istri yang kemudian menjadikan mereka dua insan yang berbahagia dalam berkeluarga.

Memang terdapat beberapa orang pria seperti Jay dan Richard yang tidak menghargai sebuah ikatan dalam sebuah hubungan. Ikatan membuat mereka tidak bebas bergaul dan bagi pria-pria seperti ini pacaran ya pacaran saja, tidak perlu serius, dan enjoy it. Prinsip itulah yang membuat mereka suka menggoda para perempuan sehingga kekasihnya lebih dari satu. Ideologi yang berkembang di masyarakat bahwa pria dengan ciri-ciri ini adalah seorang playboy.

\section{Data 003}

Pada data 003, dapat dilihat bahwa Mel, si pelayan cafe sangat kecewa dengan tingkah pria-pria yang menggodanya.

Saat seorang perempuan benarbenar merasa dirinya tidak dihargai oleh kaum laki-laki, dilecehkan, direndahkan, dihina, dan tidak bisa berbuat apa-apa maka kata-kata negatif bisa menjadi pilihan terakhir untuknya tanpa dia sadari bahwa ucapannya adalah sebuah sumpahan yang mungkin akan benar-benar terjadi pada beberapa orang. Hal ini merupakan ideologi yang berkembang di masyarakat dari dulu dan sering dilakukan oleh wanita yang merasa dirinya tidak dihargai.

Rasa marah yang timbul akibat perasaan yang tersakiti sudah terlalu sering terjadi pada setiap orang. Hal tersebut sangat manusiawi. Bahkan orang yang sangat sabar pun bisa merasakan marah dan emosi ketika sudah tidak tertahankan lagi. Marah yang memuncak dan emosi yang tinggi akan menutupi pikiran seseorang dan kesadarannya, sehingga akan membuat seseorang secara tidak sadar mengucapkan atau melontarkan katakata yang menyakitkan. Dalam keadaan yang sangat marah, seseorang akan berpikiran negatif dan mengekspresikannya dengan kata-kata yang negatif pula, karena sangat sulit untuk berpikir positif pada saat itu.

\section{Data 004}

Psikolog adalah seorang yang ahli dalam bidang praktik psikologi, bidang ilmu pengetahuan yang mempelajari tingkah laku dalam proses mental seseorang. Seseorang yang mengalami masalah dalam pertumbuhan psikolognya akan datang untuk berkonsultasi kepada psikolog.

Pada Data 004 terdapat tiga orang pria mengalami hal-hal aneh dalam diri mereka. Mereka lalu memutuskan untuk datang ke psikolog. Psikolog tersebut mengklaim bahwa mereka mengalami Gender Diasyphora Syndrome yaitu sebuah gejala di mana seorang pria secara perlahan memiliki perubahan sikap dan perilaku sebagai seorang wanita. Pasien ini merasa bahwa identitas gender mereka tidak sesuai dengan seks biologis mereka yang sebenarnya. Hal ini dapat mengakibatkan kecemasan atau depresi. Ini dapat mempengaruhi pilihan mereka dari mitra seksual, tampilan maskulin menjadi feminim atau sebaliknya, 
tingkah laku, konsep diri, dan gaya berpakaian.

\section{Data 005}

Pada data 005, tampak bahwa Affandy, Jay, dan Richard mendatangi seorang guru untuk berkonsultasi tentang kejadian-kejadian yang mereka alami.

Di alam semesta ini termasuk dunia kita, segala sesuatu yang timbul karena ada sebab. Ini merupakan sebuah ideologi yang berkembang di masyarakat. Dengan kata lain, jika ada aksi pasti akan timbul reaksi. Hal ini merupakan hukum alam yang berlaku atas segala sesuatu di dunia ini. Hukum alam ini mengajarkan kepada kita semua agar keberadaan hukum alam ini dapat diterima dan bukan ditolak atau dibantah dengan berbagai alasan. Hukum alam yang di dalamnya termasuk ada hukum karma (hukum perbuatan) itu adil, tepat waktu, tidak memihak, dan tidak bisa tebang pilih.

\section{Data 006}

Melalui pemahaman konotasi pada data 006, mereka menyadari bahwa perubahan yang mereka alami dikarenakan oleh kesalahan yang pernah mereka perbuat.

Kesalahan tidak akan diakui sampai kesalahan itu terjadi. Disebut kesalahan karena pada awalnya seseorang yang melakukannya tidak mengira bahwa perbuatannya itu salah. Itulah sebabnya setelah ada penyesalan, maka seseorang harus mulai mengkaji kesalahannya sehingga meminimalkan kesalahan yang sama. Ideologinya adalah ketika kita menyadari kesalahan kita berarti kita sudah melakukan kesalahan.

\section{Data 007}

Pada data 007 dapat dilihat bahwa Affandy melakukan sesuatu hal yang tidak biasa ia lakukan kepada istrinya. Dia lebih perhatian dan peduli.

Mitos atau kebiasaan yang sudah dilakukan turun-temurun adalah ketika suami mau makan, istri wajib menyiapkan makanan untuk suami sampai yang menyendok dan memberikan lauk ke dalam piring suami. Namun, dalam adegan ini, Affandy merombak mitos itu bahwa laki-laki pun bias melakukan hal seperti itu kepada istri sebagai bentuk kasih sayangnya.

\section{Data 008}

Melalui pemahaman pemaknaan konotasi pada data 008, dijelaskan bahwa Jay mulai merasa risih dengan pekerjaannya sendiri yaitu mengeksploitasi sensualitas wanita untuk penjualan produk perusahaan tempat ia bekerja.

Jasa Sales Promotion Girl (SPG) sudah kerap digunakan untuk menjual suatu produk. Sebab menggunakan jasa para perempuan muda nan cantik itu diyakini bisa mendongkrak penjualan. Berpakaian seksi menjadi salah satu senjata utama para SPG untuk menarik perhatian pengunjung.

Dalam adegan ini Grace merombak ideoloi-ideologi yang berkembang selama ini bahwa dalam menjual suatu produk tidak harus memperlihatkan sensualitas wanita, tetapi esensi dari produk itu adalah yang terpenting.

\section{Data 009}

Melalui pemahaman konotasi pada data 009, dapt dilihat bahwa Richard diputuskan oleh pacar-pacarnya dalam waktu yang bersamaaan.

Bagi seorang playboy diputuskan cewek sudah menjadi hal biasa baginya sehingga dia tidak teralu memikirkan karena toh dia bisa mencari lagi dengan bermodalkan rayuan mautnya. Namun, 
dalam adegan ini saat Richard yang adalah seorang playboy merasa sangat sedih. Pria playboy juga akan ada di titik di mana dia akan ditinggalkan, merasa kesepian di saat dia membutuhkan kasih sayang dari orangorang terdekatnya.

\section{Data 010}

Pada pemaknaan konotasi data 010, dijelaskan bahwa Affandy, Jay, dan Richard saling menguatkan dan mereka memutuskan untuk mencari Mel. Gambar di atas menunjukkan tiga orang pria yang sedang sama-sama menghadapi masalah, tetapi tetap saling menguatkan dan saling share untuk mendapatkan jalan keluar.

\section{SIMPULAN}

Penelitian mencakup tiga pembahasan yaitu makna denotasi dan makna konotasi serta mitos. Berdasarkan rumusan masalah pada penelitian ini, maka dapat dibuat simpulan sebagai berikut.

Pertama, makna denotasi bersifat langsung, yaitu makna khusus yang terdapat dalam suatu tanda dan pada intinya dapat disebut juga sebagai gambaran sebuah petanda. Makna denotasi dan makna konotasi dalam penelitian ini memberikan pemahaman kepada kita bahwa pentingnya bersikap sopan dan menghargai seorang perempuan dan kepada siapa pun. Karena apa pun yang kita tabur di dunia ini, baik itu perkataan, sikap baik dan buruk kepada sesama, kita akan menuainya suatu hari nanti.

Kedua, Mitos dalam penelitian ini adalah di saat Affandy, Jay, dan Richard mendatangi seorang psikolog dan psikolog tersebut mengklaim bahwa mereka mengalami Gender Diasyphora Syndrome yaitu sebuah gejala di mana seorang pria secara perlahan memiliki perubahan sikap dan perilaku sebagai seorang wanita.

\section{DAFTAR PUSTAKA}

Djajasudarma, F. (2006). Metode Linguistik-Ancangan Metode Penelitian dan Kajian. Bandung: PT Refika Aditama.

Kountur, R. (2009). Metode Penelitian. Edisi Revisi. Jakarta: Buana Printing.

Mahsun. (2007). Metode Penelitian Bahasa: Tahapan Strategi, Metode, dan Tekniknya. Edisi Revisi 3. Jakarta: PT Raja Grafindo Persada.

Mudjiono, Y. (2011). Kajian Semiotika dalam Film. Jurnal Ilmu Komunikasi, 1(1), hlm: 125-138.

Octaviand, A. (2015). "3 dara". Video. Jakarta: MNC Picturs.

Wirianto, R. dan Girsang, L.R.M. 2016. Representasi Rasisme pada Film "12 Years A Slave" (Analisis Semiotika Roland Barthes). Jakarta. 